\title{
The Effectiveness of a Two-day Inclusion Workshop on Teachers'Attitudes, Understanding, and Competence in Inclusive Education
}

\author{
Sunardi ${ }^{1,}$, Maryadi $^{1}, \&$ Sugini ${ }^{1}$ \\ ${ }^{1}$ Special Education Program, Sebelas Maret University, Solo, Indonesia \\ *Corresponding author: Special Education Program, Sebelas Maret University, Jl.Ir.Sutami 36A, Kentingan Solo, \\ 57126, Indonesia. E-mail: sunardi.ipuns@gmail.com
}

Received: August 20, 2014

Accepted: September 17, $2014 \quad$ Online Published: October 13, 2014

doi:10.5430/wje.v4n5p77

URL: http://dx.doi.org/10.5430/wje.v4n5p77

\begin{abstract}
The previously UNESCO initiated policy of inclusive education has been adopted by the Indonesian government since 2003. As a new policy, inclusion will require many changes in the existing system of education which tends to be segregative. This research investigated the effects of a two-day workshop on parents attitudes, teachers' competence and knowledge related to inclusive education..

The subjects of the study were 50 parents and 50 teachers of 25 primary schools from 25 subdistricts in the district of Wonogiri, Indonesia. They took part in a two-day workshop in inclusive education using active learning modes of presentation. Teachers' knowledge was measured using a written test, while parents' attitudes and teachers' competence were measured using likert type scales.

The results showed that:

1. The two-day workshop in inclusive education significantly improved parents' attitudes toward inclusive education. The mean score of parents' attitudes before workshop was 137,26 ( $\mathrm{SD}=17.383)$, and the mean score after workshop was 148,46 with a standard deviation of 15,439. A t-test for correlated means resulted in a $\mathrm{p}=0.000$.

2. The two-day workshop significantly improved teachers' knowledge about inclusive education. The mean score of teachers'knowledge before workshop was 57.60and the mean score after workshop was 67.36, both were below the mastery criteris of 70. A T-test for correlated means resulted a $\mathrm{p}$ value of 0,00 ,indicating a signicant improvement of knowledge.

3. The two-day workshop also significantly improved teachers' feeling of competence working in inclusive classrooms. The mean score of teachers' competence before workshop was 334,82 ( $\mathrm{SD}=69,857)$ and the mean score after workshop was372,56 (SD=72,505). A t-test for correlated means resulted a $\mathrm{p}$ value of $=0.000$.
\end{abstract}

Keywords: inclusion; workshop; attitudes; knowledge; competence

\section{Introduction}

Article 31 item 1 of the 1945 Indonesian Constitution and chapter III item 5 of the 1989 Indonesian Law of National Educational System guarantee that all citizens, including special educational need children (SEN) have the same right for education. Three types of schools are available for SEN, i.e special schools, special primary schools, and integrated schools. Special schools, the oldest type, educate children with the same type of exceptionality. There are special schools for the visually impaired (type A), special schools for the hearing impaired (type B), special schools for the mentally retarded (type C), special schools for the physically handicapped (type D), and special schools for those with emotional - behavior problems (type E). Special primary schools educate children with all types of exceptionalities in the same schools. Whereas integrated schools are regular schools that also admit SEN children with the same curriculum, same teachers, same facilities, same learning activities, and same evaluation. Previously, only visually impaired childen with at least normal IQs were admitted.

Special schools are mostly located in the district capitols, whereas SEN children can be found everywhere, not only 
in towns, but in villages, in remote areas. Consequently, many SEN children do not get access to education, especially those from the low economic families; special schools are far from their homes, whereas nearby regular schools refuse to admit them because of their feeling of incapability of serving these children. Only a few of SEN children go to nearby regular schools, however, due to the inavailability of special educational services, they face the risks of not being promoted at the end of academic year and finally drop out. This will affect on the attainment of 'education for all' policy in the country.

The 2003 Indonesian Law of National Education System offers this new alternative of special education provision. Item 15 of the law states that special education is education for SEN children and those with special talents which can be provided inclusiveley in regular schools or in special schools at the primary and highschool levels. This item is a breaktrough in the provision of special education, i.e in inclusive settings, which is also the most recent trend in special education servives.In inclusive education, SEN children learn with their (normal) peers, based on the premise that, in reality, the community consists of normal and SEN people who live without disrcimination. SEN children have equal rights and oppotunities for educational services in regular schools. Inclusive education is expected to solve the existing problem of providing education for SEN children in Indonesia with specific geographic condition. Building new special schools in rural areas will be a high cost policy.

Sapon-Shevin (O'Neil, 1994/1995) defines inclusive education as a special education service system that requires that all SEN children be educated in nearby regular schools along with their peers. Sapon-Shevin emphasizes the reorganization of regular schools to become a community that supports the fulfillment special needs of each student, rich in resources and supports from all teachers and other students. Whereas according to StainbackdanStainback (1990), inclusive schools are the ones which admit all types of learners in the same classrooms. These schools offer proper and challenging educational programs to meet the special needs and capabilities of every student and support from all teachers so that all students succeed. The same definition is provided by Staub and Peck (1994/1995), inclusive education is placing SEN children, mild, moderate, or severe, in regular classrooms. Regular classrooms are the most proper placement of all types and levels SEN children.Vaughn, Bos, and Schumm (2000), however, states that in practice, the term inclusion is used interchangably with the term mainstreaming, i.ethe provision of proper educational services for SEN children based on their individual needs. SEN children must be placed in the least restrictitive environment, ranging from regular class without any additional special services, regular class with additional supports in the class, regular class with additional pull out services, special class with opportunities to stay in regular class in specific subjects, full time special class, special school, and special places. The philosohy is inclusive, with a variety of placement alternatives.

One of the most important characteristic of inclusive schools is a cohesive community, caring, accepting, and responsive towards individual needs of each student. Sapon-Shevin (O'Neil1994/1995) identifies five profiles of instruction in inclusive schools:

i. Creating and keeping a warm classroom community, accepting heterogenety, and valuing differences. Inrelation to capability, physical condition, social economic condition, races, religions, etc.

ii. Implementing a multilevel curriculum and multimodality of instruction, moving from traditional structured, textbook based, or basal material instruction to instruction which tends to be cooperative, thematic, employing critical thinking, problem solving, and authentic assessment.

iii. Preparing and motivating teachers to teach interactively, where students work collaboratevely, teach each other, and actively participate in their own education and their peers.

iv. Continuously motivating teachers and students and removing barriers related to professional isolation, promoting team teaching, collaboration and consultation, a variety of techniques for assessing performance and understanding, and individual assisstance in working woth a group of students.

v. Involving parents meaningfully in the planning process, including in the develoment of Individualized Education Plan.

Movement toward inclusion varies in different parts of the world. In Alberta, Canada, for example, movement towards adopting this approach universally has been slow, despite a considerable amount of research demonstrating the efficacy of inclusive education and longstanding international support for the practice from bodies such as UNESCO (Loreman, McGhie-Richmond, Barber, Lupart, 2009). In New Zealand, all SEN children have an equal right for education in inclusive setting as non-SEN children, however, there are day schools and residential schools supporting students who are hearing or vision impaired, have severe behavioural needs, or educational or social and emotional needs with a slow rate of learning (Powell, 2012). The main barriers in the early stages included physical 
and attitudinal barriers, compounded by lack of institutional resources and poor understanding of disability issues. In addition to the provision of physical resources, teachers must be well prepared to teach diverse student populations and meet the needs of all learners requires an understanding of the principles and practices that underpin inclusive education environments. India implemented Integrated Education of Disabled Act in 1995, emphasizing appropriate educational placement of children with disabilities based on their needs (Narayan and Rao, 2006). It was estimated that about 15,000 schools enrolled about 60,000 SEN children, but the drop-out rate was high due to lack of support services and trained teachers to educate children with disabilities. In Botswana and Mozambik, althoug, most principals who were in general favourable about the inclusion of learners with disabilities, they preferred learners with certain categories of disabilities. They preferred to include learners with learning disabilities, while the least preferred group were those who require major curriculum accommodation such as those with hearing, visual and intellectual impairments (Mukhopadhyay \& Musengi, 2012). Barriers in the implementation of inclusive education included lack of trained personnel, lack of time, lack of parental involvement, large class-size, and general resistance to change by regular teachers. Brunei Darussalam has adopted inclusive education as its policy for educating children with special needs since 1998 (Abdullah and Abosi, 2014). In a survey to 113 regular classroom teachers in 18 inclusive schools, it was found out that teachers supported the inclusion of children who are academically underachievers, but did not respond positively to the question of having children with diverse needs in their care, they felt that they were not prepared to teach and care for children with diverse abilities.

The implementation of inclusive education in Indonesia requires many changes in the regular schooling which, for a long time, has been characterized as traditional, highly controlled and teacher centered instruction. The inclusive policy in the 2003 Law of Education is further ellaborated in the 2003 Government Regulation of Special Education and Special Service Education (in Indonesian context, special education is designed for handicapped or talented children, whereas special service education is designed for normal children who do not get access to regular education due to such factors as poverty, remote location). The regulation states that every district must operate at least one inclusive highschool and every sub-district must operate at least one inclusive primary and one inclusive secondary school. Since 2005, the government has also provided block grants for districts to initiate inclusive schools, which can be spent for such activities as teacher training, procurement of special equipment, or building renovation. This policy affected the rapid growth of inclusive schools. By 2008, there were 925 inclusive schools in Indonesia consisting of 790 schools admitting disabled students and 135 schools with accelerated programs for the gifted from the kindergarten to highschool levels (Directorate of Special Education, 2008)

In a study involving 186 inclusive schools with a total student body of $24,412,12$ percent of which $(3,419)$ were students with special needs Sunardi, et ell, (2011) found out that, in terms of institutional management, the majority of inclusive schools had developed strategic plans (for inclusion), legally appointed coordinators, involved related and relevant parties, and conducted regular coordination meetings. However, there were still many schools that had not restructured their school organizations. In terms of student admission / identification / assessment, 54 percent of schools set a quota for SEN students. Only 19 percent applied a selection process in student admission, half of which used different procedures for SEN candidates. Approximately 50 percent of inclusive schools had modified their curriculum, including a variety of standards. In terms of instruction, 68 percent of inclusive schools reported that they modified their instructional process. Only a few schools, however, provided special equipment for students with visual impairment, physical impairment, speech and hearing problems, autism and gifted and talented students. In a student evaluation, more than 50 percent reported that test items, administration, time allocations, and students' reports were modified. For the national exam, this number decreased dramatically. Finally, external supports in the forms of funding, coaching, and facilities were mostly provided by provincial and central governments through the Directorate of Special Education.

In another study, (Sunardi, 2012) developed a data base for the implementation of inclusive education in the district of Wonogiri, one of the largest district in Central Java, Indonesia.The results showed that the prevalence of special needs children was $16 \%$ of the school aged population, mostly learning disabled children. The majority of them were in regular schools. General education facilities were adequate in mopst schools, but there were limited special facilities for special needs students. Teachers had limited experience related to inclusive education. Similarly, access to special facilities were limited due to the limited number of special schools in the region.

In a review of previous research findings on the implementation of inclusion, Walker and Ovington (1999) reveal that inclusion had a variety academic effects on students and social effects on students, teachers and the community, depending of SEN students' ages, types of disabilities, severity of academic disabilities, supports of teachers, and availability of resources. They state the staff and its training was a factor in successful inclusion. Training should focus on teachers, aids, and specialists to recognize problems and develop plans to address them. Administrators 
were trained on how to "nurture and develop administrative leadership in support of inclusion.This process must include (1) consensus building, (2) shared responsibility, and (3) transfer of ownership.

A variety of resources have been provided by the Indonesian government for the implementation of inclusive education policy. The Ministry of Education and Culture has conducted many enculturization programs of inclusive education, mostly consisting of general lectures, workshops, and provision of education supplies. In addition, block grants have also been provided for district / local governments for the same goal. Very few studies have been conducted to see the effectivenes of those programs, including which work and which do not.

The goal of this research is to investigate the effects of a two-day inclusive education workshop on parents' attitudes, teachers' understanding and competence related to inclusive classrooms. The workshop was conducted using an andragogical approach based on the constructive philosophy of education (Ornstein and Hunkins, 2013), assuming that learners come to the classroom not without anything but bringing their own previous knowledge and experiences, teachers facilitate them in reconstructing new knowledge and understanding. In this workshop, the participants were adult teachers with different unsdrestanding and experiences related to SEN and inclusive education. A guidebook on inclusive education was written using a pictorial question-answer format, including such topics as types of SEN children, identificasion-assessment, speficic characteristics-needs of SEN children, adaptations in reguler classrooms for SEN children. Copies of the guidebook were sent to the participants one week prior to the workshop, so that they had time to read. During the workshop, the participants were involved in problem solving discussions, related to their experiences with SEN childfren and the application of important points in the guidebook in their work.

More specifically, the objectives are to analyze whether:

i. The two-day workshop would have positive effects on teachers' understanding about inclusive education.

ii. The two-day workshop would have positive effects on parents' attitudes toward inclusive education.

iii. The two-day workshop would have positive effects on teachers' competence in invlusive education.

\section{Method}

\subsection{Participant (Subject) Characteristics}

This research was conducted in the district of Wonogiri, one of the largest district in Central Java Province with 25 subdistricts. The subjects consisted of 50 parents and 50 teachers from 25 primary schools in 25 subdistricts. The selection of schools was done by the heads of the Subdistrict Office of Education, by assuming that the schools could become resource schools in the context of inclusive education.

\subsection{Research Design}

This is a quasi expereimental research with a pretest posttest design. Before and after the workshop, the teachers were pretested and postted on their understanding and feeling of competence teaching inclusive classrooms, whereas the parents filled out an attutide scale. The two day workshop used an andragogic mode of presentation with active learning activities. A question - answer type of module about inclusive education was prepared for the participants, and each session consisted of discussion, brain storming, questions - answers with as minimal lecturing activities as possible.

\subsection{Instruments and Analysis}

Teachers' understanding was measured using a test with a five option multiple choice format, developed based on the content of the module which is presented in table 1. The original test consisted of 55 items. Based on the result of a try out to 25 teacher education students at SebelasMaret University, only 45 items were valid with a reliability level of 0.948 . For practical reasons in calculation, 40 items were used. 
Table 1. Test Blue Print

\begin{tabular}{|c|c|c|c|c|c|c|c|}
\hline No & Themes & & Sub Themes & & Indikcators & $\begin{array}{l}\text { Total } \\
\text { items }\end{array}$ & $\begin{array}{l}\text { No of } \\
\text { items }\end{array}$ \\
\hline \multirow[t]{17}{*}{1.} & Implementation & 1.1 & SEN children & 1.1 .1 & Defining SEN children & 2 & $1-2$ \\
\hline & $\begin{array}{l}\text { of inclusive } \\
\text { education }\end{array}$ & 1.2 & & 1.1 .2 & $\begin{array}{l}\text { Identifyng the characteristics of } \\
\text { SEN chuildren }\end{array}$ & 6 & $3-8$ \\
\hline & & & & 1.1 .3 & Identifyng needs of SEN children & 2 & $9-10$ \\
\hline & & & & 1.1 .4 & $\begin{array}{l}\text { Understanding instruments for } \\
\text { SEN children identification }\end{array}$ & 5 & $11-15$ \\
\hline & & 1.3 & $\begin{array}{l}\text { Iinclusive } \\
\text { education }\end{array}$ & 1.2 .1 & $\begin{array}{l}\text { Explaining the historical } \\
\text { background of inclusive } \\
\text { education }\end{array}$ & 3 & $16-18$ \\
\hline & & & & 1.2 .2 & $\begin{array}{l}\text { Explaining the legal foundation } \\
\text { of inclusive education }\end{array}$ & 5 & $19-23$ \\
\hline & & & & 1.2 .3 & $\begin{array}{l}\text { Comparing segregation, } \\
\text { mainstreaming, and inclusion. }\end{array}$ & 3 & $24-26$ \\
\hline & & 1.4 & $\begin{array}{l}\text { Curriculum, } \\
\text { instruction, and }\end{array}$ & 1.3 .1 & $\begin{array}{l}\text { Describing the strengths and } \\
\text { weaknesses of inclusive }\end{array}$ & 5 & $27-31$ \\
\hline & & & evaluation in & & education & 3 & $32-34$ \\
\hline & & & $\begin{array}{l}\text { inclusive } \\
\text { education }\end{array}$ & 1.3 .2 & $\begin{array}{l}\text { Describing models for curriculum } \\
\text { and material development }\end{array}$ & 3 & $35-37$ \\
\hline & & & & 1.3 .3 & $\begin{array}{l}\text { Describing models of } \\
\text { instructional modification }\end{array}$ & 3 & $38-40$ \\
\hline & & & & 1.3 .4 & $\begin{array}{l}\text { Preparing specific instructional } \\
\text { media in inclusive education }\end{array}$ & & \\
\hline & & & & 1.3 .5 & $\begin{array}{l}\text { Describing procedures of } \\
\text { assessment modification }\end{array}$ & 4 & $41-44$ \\
\hline & & 1.5 & $\begin{array}{l}\text { Stakeholders in } \\
\text { inclusive }\end{array}$ & 1.5 .1 & Defining stakeholders & 1 & 45 \\
\hline & & & education & 1.5.2 & $\begin{array}{l}\text { Identifying stakeholders in } \\
\text { inclusive education }\end{array}$ & 5 & $46-50$ \\
\hline & & & & 1.5.3 & $\begin{array}{l}\text { Identifying roles of } \\
\text { stakeholders in inclusive } \\
\text { education }\end{array}$ & 5 & $41-55$ \\
\hline & Total & & & & & 55 & \\
\hline
\end{tabular}

Teachers' feeling of competence was measured using a Likert type scale with five options. The scale was first developed by Sari Rudiyati (2010) fo her doctoral dissertation in Educational Research and Measurement at the State University of Yogyakarta. The scale was a self report type, adapted from the Teachers' Competence Stantards first developed by the National Board of Educational Standards, i.e pedagogical competence (41 items), personality competence (20 items), social competence (13 items), and professional competence (51 items).

Attitudes toward inclusive education was also measured using a Likert type scale with five options, requiring respondents to indicate their agreement - disagreement to descriptive statements about inclusive education. The original scale consisted of 50 positive and negative statements (see tabel 2 for the blue print). The scala was tried out to 35 respodents, consisting of students of non-special education teacher education programs at SebelasMaret University, parents of SEN students, parents of non-SEN students, inclusive primary school teachers, and regular shool teachers, all in the town of Solo. The results showed that 35 items were valid with a realibility level of 0.865 . 
Table 2. Attitude Scale Blue Print

\begin{tabular}{llcrc}
\hline \multicolumn{1}{c}{ COMPONENTS } & \multicolumn{1}{c}{ INDICATORS } & $\begin{array}{c}\text { POSITIVE } \\
\text { ITEMS }\end{array}$ & $\begin{array}{c}\text { NEGATIVE } \\
\text { ITEMS }\end{array}$ & $\begin{array}{c}\text { TOTAL } \\
\text { ITEMS }\end{array}$ \\
\hline Cognitive & a. Understanding education for SEN & 4 & 3 & 7 \\
& b. Understanding inclusive education & 5 & 1 & 6 \\
Affektive & $\begin{array}{l}\text { Feeling about the existence of SEN in } \\
\text { regular schools }\end{array}$ & 9 & 10 & 19 \\
Psychomotoric & $\begin{array}{l}\text { Roles of community in inclusive } \\
\text { education }\end{array}$ & 11 & 7 & 18 \\
TOTAL & & 29 & 21 & 50 \\
\hline
\end{tabular}

Data about teachers' understanding of and feeling about inclusive education and parents' attitudes were then anayzed usinga a t-test for correlated means.

\section{Results}

\subsection{Effects on Parents' Attitudes}

The mean of parents' attitude scores prior to the workshop was 137.26 with a standard deviation of 17.383 , whereas the mean of scores after workshop was 148.46 with a standard deviation of 15.439 (see table 3). With a five option Likert type scale consisting of 35 statements (possible lowest score of 35 and possible highest score of 175 with a mid score of 105), in general, parents hold positive attitudes toward inclusion, even before the workshop.

Table 3. Paired Samples Statisticsof Parents' Attitudes

\begin{tabular}{rrrrrr}
\hline & & Mean & N & Std. Deviation & Std. Error Mean \\
\hline \multirow{2}{*}{ Pair 1 } & pre-test & 137,26 & 50 & 17,383 & 2,458 \\
& post test & 148,46 & 50 & 15,439 & 2,183 \\
\hline
\end{tabular}

As seen in table 4 , the correlational analysis showed a value of $r=764$ with $p<0.00$, meaning that there was a highly significant relationship between attitudes before and after workshop.

Table 4. Paired Samples Correlationsparents' Attitudes

\begin{tabular}{|c|c|c|c|c|}
\hline & & $\mathrm{N}$ & Correlation & Sig. \\
\hline Pair 1 & pre-test \& post test & 50 & ,764 &, 000 \\
\hline
\end{tabular}

Whereas table 5 presents the results of the t-test analysis, showing a t value of 6,93 with $p<0.00$, which means that there was a significant difference between attitudes befor and after workshop.

Table 5. T-Test for Correlated Means

\begin{tabular}{|c|c|c|c|c|c|c|c|c|c|c|}
\hline & & & \multicolumn{5}{|c|}{ Paired Differences } & \multirow[b]{3}{*}{$\mathrm{T}$} & \multirow[b]{3}{*}{$\mathrm{df}$} & \multirow{3}{*}{$\begin{array}{c}\text { Sig. } \\
\text { (2-tailed) }\end{array}$} \\
\hline & & & \multirow[b]{2}{*}{ Mean } & \multirow{2}{*}{$\begin{array}{c}\text { Std. } \\
\text { Deviation }\end{array}$} & \multirow{2}{*}{$\begin{array}{l}\text { Std. Error } \\
\text { Mean }\end{array}$} & \multicolumn{2}{|c|}{$\begin{array}{c}95 \% \text { Confidence Interval } \\
\text { of the Difference }\end{array}$} & & & \\
\hline & & & & & & Lower & Upper & & & \\
\hline Pair 1 & $\begin{array}{l}\text { pre-test } \\
\text { post test }\end{array}$ & - & $-11,200$ & 11,423 & 1,615 & $-14,446$ & $-7,954$ & $-6,933$ & 49 &, 000 \\
\hline
\end{tabular}

The two day workshop in inclusive education using an active learning mode of presentation significantly improved parents' attitudes towards inclusive education.

\subsection{Effects on Teachers' Competence}

The mean score of teachers' competence prior to the workshop was 334.82 with a standard deviation of 69.857 , whereas the mean score after the workshop was 372.56 with a standard deviation of 72.51 (see table 6). Teachers' competence to teach inclusive classrooms was in general at the high level (the test consisted of 125 items with five 
options, thus the mid score was 312.5)

Table 6. Paired Samples Statisticsteachers' Competence

\begin{tabular}{llrrrr}
\hline & & Mean & N & Std. Deviation & \multicolumn{1}{c}{ Std. Error Mean } \\
\hline Pair 1 & pre-test & 334,82 & 50 & 69,857 & 9,879 \\
& post-test & 372,56 & 50 & 72,505 & 10,254 \\
\hline
\end{tabular}

Table 7 presents a correlational analysis between the two sets of scores, and it showed a value of $r=0.893$ with $\mathrm{p}<0.00$. There was a highly significant correlation between teachers' competence before and after workshop.

Table 7. Paired Samples Correlationsteachers' Competence

\begin{tabular}{|c|c|c|c|c|}
\hline & & $\mathrm{N}$ & Correlation & Sig. \\
\hline Pair 1 & pre-test \& post-test & 50 & 893 &, 000 \\
\hline
\end{tabular}

Table 8 presents the t-test analysis results, showing a $t$ value of 8.071 , with $\mathrm{df}$ of 49 , it was significant at $\mathrm{p}, 0.00$.

Table 8. T-Test for Correlated Means Teachers' Competence

\begin{tabular}{|c|c|c|c|c|c|c|c|c|c|c|}
\hline \multirow[b]{4}{*}{ Pair } & \multirow[b]{4}{*}{ pre-test } & \multicolumn{6}{|c|}{ Paired Differences } & \multirow[b]{3}{*}{$\mathrm{t}$} & \multirow[b]{3}{*}{$\mathrm{df}$} & \multirow{3}{*}{$\begin{array}{c}\text { Sig. } \\
\text { (2-tailed) }\end{array}$} \\
\hline & & \multirow{2}{*}{\multicolumn{2}{|c|}{ Mean }} & \multirow{2}{*}{$\begin{array}{c}\text { Std. } \\
\text { Deviation }\end{array}$} & \multirow{2}{*}{$\begin{array}{c}\text { Std. Error } \\
\text { Mean }\end{array}$} & \multicolumn{2}{|c|}{$\begin{array}{l}95 \% \text { Confidence } \\
\text { Interval of the } \\
\text { Difference }\end{array}$} & & & \\
\hline & & & & & & Lower & Upper & & & \\
\hline & & - & $-37,740$ & 33,066 & 4,676 & $-47,137$ & $-28,343$ & $-8,071$ & 49 &, 000 \\
\hline
\end{tabular}

There was a significant difference between the feeling of competence before and after workshop. Teachers became significantly more confident teaching inclusive classrooms after partisipating in a two day workshop.

\subsection{Effects on Teachers' Understanding.}

The mean score of teachers' understanding before workshop was 57.6 with a standard deviation of 12.7 , whereas the mean score after workshop was 67.36 with astandard deviation of 10.62 (see table 9). Using a 0-100 scale of scoring with a mastery criteria of 70, teachers' understanding about inclusive education was still below the criteria.

Table 9. Paired Samples Statistics Teachers' Understanding

\begin{tabular}{llrrrr}
\hline & & Mean & N & Std. Deviation & Std. Error Mean \\
\hline Pair 1 & pretes & 57,60 & 50 & 12,707 & 1,97 \\
& posttes & 67,36 & 50 & 10,617 & 1,501 \\
\hline
\end{tabular}

Table 10 presents the correlational test of the two sets of scores, showing a value of $r=0.732$, with probability value of $p<0.00$. There was a highly significant relation between teachers' understanding of inlcusive education before and after workshop.

Tabel 10. Paired Samples Correlations

\begin{tabular}{|c|c|c|c|c|}
\hline & & $\mathrm{N}$ & Correlation & Sig. \\
\hline Pair 1 & pretes\&posttes & 40 & ,732 &, 000 \\
\hline
\end{tabular}

Table 11 presents the $t$-test results, showing a value of $t=7.881$. With a df of 49 , the calculated $t$ was significant at $\mathrm{p}<0.00$.

Tabel 11. Paired Samples Test of Teachers' Understanding

\begin{tabular}{|c|c|c|c|c|c|c|c|c|c|}
\hline & \multicolumn{5}{|c|}{ Paired Differences } & \multirow[b]{3}{*}{$\mathrm{T}$} & \multirow[b]{3}{*}{$\mathrm{df}$} & \multirow[b]{3}{*}{ Sig. (2-tailed) } \\
\hline & & \multirow[b]{2}{*}{ Mean } & \multirow{2}{*}{$\begin{array}{c}\text { Std. } \\
\text { Deviation }\end{array}$} & \multirow{2}{*}{$\begin{array}{l}\text { Std. Error } \\
\text { Mean }\end{array}$} & \multicolumn{2}{|c|}{$\begin{array}{l}95 \% \text { Confidence } \\
\text { Interval of the } \\
\text { Difference }\end{array}$} & & & \\
\hline & & & & & Lower & Upper & & & \\
\hline Pair 1 & $\begin{array}{l}\text { pretes - } \\
\text { posttes }\end{array}$ & $-9,760$ & 8,756 & 1,238 & $-12,249$ & $-7,271$ & $-7,881$ & 49 &, 000 \\
\hline
\end{tabular}

Teachers' understanding about inclusive education after participating in a two day workshop was significantly higher than their understanding before workshop. 


\section{Discussion and Recommendation}

The two day workshop in inclusive education using an active learning mode of presentation significantly improved parents' attitudes towards inclusive education.This finding supports the finding of a slightly similar research by Sunardi (1987) who investigated the effectiveness of an introductory course in special education on teacher trainees' atiitudes towards mainstreaming. According to Susanto (1977), an attitude is a person's tendency to react positively or negatively to a situation, person, or object based on his experiences. Taking part in a two day inclusive education workshop or a semester special education course can be a valuable experince that improves their attitudes. Mathis (2002) described training / workshop as a process of achieving a specific level of competence, and this research, it also improved attitudes.

There was a significant difference between the feeling of competence before and after workshop. Teachers became significantly more confident teaching inclusive classrooms after partisipating in a two day workshop. Teachers' competence is an integration of knowledge, understanding, value, attitudes, skills, and interests. In the context of inclusive education, teachers' competence will be reflected in their cognitive, affective, and psychomotoric behaviors teaching SEN students in regular classroom. According to Majid (2005:6), teachers' competence represents their professional quality in their roles as teachers and educators.

There are a variety of strategies of improving professional competence, participating in workshops is one of them. In this research, workshop was specifically designed as an in service traning for teachers. A question-answer format module about inclusive education was previously developed and distributed to the participants a week prior to the workshop so that they had time to read. During the workshop, an andragogic mode of presentation was used, dominated by , brain storming, discussion and small group work activities. The workshop was proven to be effective in improving their feeling of competence working with SEN students in regular classrooms.

Teachers' understanding about inclusive education after participating in a two day workshop was significantly higher than their understanding before workshop. Siswoyo (2008) states that teachers, as educators in school environment, are professional educators whose main responsibility is to teach, guide, coach, train, direct, and evaluate students. They are required to have a set of competence, in the Indonesian context called pedagogical, personality, social and professional competence. The fast development of science technology has caused a variety of changes in the life of people and community. Teachers are required to always update their professional competence in order to adapt themselves to those changes. A variety of resources and opportunities are now availbale for teachers for keeping themselves updated, including participation in relevant workshops.

In this research, teachers participated in a two day workshop, consisting of brainstorming on their experiences and ideas, discussion, and presentation, using modules that were sent to them a week before. It was not surprising that their pretest score mean was 57. Their understanding about inclusive education could come from their experience or their reading of the modules. After workshop, a significant improvement was made, although it did not reach a mastery level of $70 \%$. More efforts were still needed to better understand inclusive education.

The Indonesian Ministry of Education has already stated its committment to provide education to all children through inclusive education. As seen in previous research findings, there are many factors contributing to the success of inclusion, teachers' attitudes, support, and competence are a few of them. Workshops using an andragogical approach can be used in training teachers to work in inclusive classrooms.

\section{Acknowledgements}

The authors would like to express their gratitude to Sebelas Maret University that has provided fund for this research and to undergraduate students of Special Education Program, Eka, Enggar, Dian, Dwi, Isni, Nurul, and Priske, who have been hardworking assisstants in the implementation of this research.

\section{References}

Abdullah, N.A., \& Abosi,O. (2014). Attitudes and Concerns of Regular Teachers towards Inclusive Education in Brunei Darussalam. Asian Journal of Education and e-Learning, 1(2), 15-23.

Directorate of Special Education. (2008). Special Education in Figures. Jakarta: Ministry of National Education.

Loreman, T., McGhie-Richmond, D., Barber, J., \& Lupart, J. (2008). Student perspectives on inclusive education: a survey of grade 3-6 children in rural Canada. Journal of Whole Schooling, 5(2). 
Majid, A. (2005). PerencanaanPembelajaran: MengembangkanStandarKompetensi Guru (Instructional Planing: Developing Teachers' Competence Standards). Bandung: PT RemajaRosdakarya

Marthan, L. K. (2007). Manajemen Pendidikan Inklusif (The Management of Inclusive Education). Jakarta: The Directorate Heneral of Higher Education.

Mukhopadhyay, S., \& Musengi, M. (2012). Contrasting Visions of Inclusive Education: Comparisons from Rural and Urban Settings in Botswana and Zimbabwe. Electronic Journal for Inclusive Education, 2(10).

Narayan, J., \& Rao, L.G. (2006). Utilising Existing Resources for Inclusive Education of Children with Disabilities in India. Asia Pacific Disability Rehabilitation Journal, 17(1), 87-93.

O’Neil, J. (1994/1995). Can inclusion work? A conversation with James Kauffman and Mara Sapon-Shevin. Educational Leadership, 52(4), 7-11.

Ornstein, A.C., \& Hunkins, F.P. (2013). Curriculum: Foundations, Principles, and Issues. Boston: Pearson

Powell, D. (2012). A Review of Inclusive Education in New Zealand. Electronic Journal for Inclusive Education, 2(10), article 4.

Sari Rudiyati (2010). The Development of Kindergarten Teachers' Competence in Inclusive Education. Unpublished doctoral dissertation, The State University of Yogyakarta.

Siswoyo, Dwi. (2006). IlmuPendidikan (Education Science). Yogyakarta. UNY Pers.

Stainback, W., \& Stainback, S. (1990). Support Networks for Inclusive Schooling: Independent Integrated Education. Baltimore: Paul H. Brooks.

Staub, D., \& Peck, C.A. (1994/1995). What are the outcomes for nondisabled students? Educational Leadership, 52(4), 36-40.

Sunardi (1997). Kecenderungan dalam Pendidikan LuarBiasa (Trends in Special Education). Jakarta: Ditjen Dikti.

Sunardi (2012). Database for Implementation of Inclusive Education in the District of Wonogiri. Sebelas Maret University, unpublished research report. .

Sunardi, Munawir Yusuf, Gunarhadi, Priyono, \& Yeager, J.L. (2011). The Implementation of Inclusive Education for Students with Special Needs in Indonesia. Excellence in Higher Education, 2(2011), 1-10

Sunardi. (1987). The Effects of an Introductory Course in Special Education on Regular Classroom Teacher Trainees' Attitudes towards Mainstreaming. Unpublished Doctoral Dissertation, The State University of New York at Albany.

Susanto (1977). Pengertian sikap (the Definition of Attitudes) Retrieved from http://5martconsultingbandung.blogspot.com/2010/10/pengertian-sikap.html (download, Thusday, February 9. 2012)

Vaughn, S., Bos, C.S., \& Schumm, J.S. (2000). Teaching Exceptional, Diverse, and AtRiskSrudents in the General Education Classroom. Boston: Allyn Bacon.

Walker, K. E., \& Ovington, J. A. (1999). Inclusion and Its Effects on Students. Electronic Journal for Inclusive Education, 1(2). 